\title{
GPs' familiarity with and use of cardiovascular clinical prediction rules: a UK survey study
}

\author{
Jong-Wook Ban ${ }^{1 *}$, Rafael Perera², Richard Stevens ${ }^{2}$ \\ ${ }^{1}$ Evidence-Based Health Care Programme, Centre for Evidence-Based Medicine, \\ University of Oxford, Oxford, UK; ${ }^{2}$ Nuffield Department of Primary Care Health \\ Sciences, Medical Science Division, University of Oxford, Oxford, UK
}

\begin{abstract}
Background: Clinical prediction rules (CPRs) can help general practitioners (GPs) address challenges in cardiovascular disease. A survey published in 2014 evaluated GPs' awareness and use of CPRs in the UK. However, many new CPRs have been published since and it is unknown which cardiovascular CPRs are currently recognised and used.
\end{abstract}

Aim: To identify cardiovascular CPRs recognised and used by GPs, and to assess how GPs' familiarity and use have changed over time.

Design \& setting: An online survey of GPs in the UK was undertaken.

Method: Using comparable methods to the 2014 survey, GPs were recruited from a network of doctors in the UK. They were asked how familiar they were with cardiovascular CPRs, how frequently they used them, and why they used them. The results were compared with the 2014 survey.

Results: Most of 401 GPs were familiar with QRISK scores, ABCD scores, CHADS scores, HASBLED score, Wells scores for deep vein thrombosis, and Wells scores for pulmonary embolism. The proportions of GPs using these CPRs were 96.3\%, 65.1\%, 97.3\%, 93.0\%, 92.5\%, and 82.0\%, respectively. GPs' use increased by $31.2 \%$ for QRISK scores, by $13.5 \%$ for ABCD scores, by $54.6 \%$ for CHADS scores, by $33.2 \%$ for Wells scores for deep vein thrombosis, and by $43.6 \%$ for Wells scores for pulmonary embolism; and decreased by $45.9 \%$ for the Joint British Societies (JBS) risk calculator, by $38.7 \%$ for Framingham risk scores, and by $8.7 \%$ for New Zealand tables. GPs most commonly used cardiovascular CPRs to guide therapy and referral.

Conclusion: The study found GPs' familiarity and use of cardiovascular CPRs changed substantially. Integrating CPRs into guidelines and practice software might increase familiarity and use.

Received: 13 January 2020

Accepted: 19 February 2020

Published: 07 October 2020

œThis article is Open Access: CC BY license (https://creativecommons.org/licenses/by/4.0/)

\section{Author Keywords:}

cardiovascular diseases, Clinical prediction rules, guidelines, general practice, surveys and questionnaires

Copyright (C) 2020, The Authors;

\section{How this fits in}

Clinical prediction rules (CPRs) can help GPs address challenges in preventing and managing cardiovascular disease. The previous study from 2014 found cardiovascular CPRs used by the majority of GPs in the UK were Framingham risk scores, QRISK scores, and Wells scores for deep vein thrombosis. The present study showed GPs predominately used QRISK scores to assess cardiovascular disease risk; and used ABCD scores, CHADS scores, HAS-BLED score, Wells scores for deep vein thrombosis, and Wells scores for pulmonary embolism for stroke, and venous thromboembolism currently. Integrating high quality CPRs into national guidelines and GPs' electronic health records (EHRs) might facilitate GPs' familiarity with and use of them in practice.

DOI:10.3399/

bjgpopen20X101081 


\section{Introduction}

Morbidity and mortality from cardiovascular disease are some of the leading sources of burden of disease in the UK, ${ }^{1}$ and pose many challenges to GPs. CPRs might help GPs address these challenges from cardiovascular disease by improving clinical outcomes, increasing efficiencies, and reducing costs. $^{2,3}$

Although many cardiovascular CPRs exist, ${ }^{4,5}$ only a few have been broadly used by GPs. ${ }^{6}$ This may be owing to the following inefficiencies in cardiovascular CPR development. First, many authors do not justify why new CPRs are needed by examining existing CPRs, ${ }^{7}$ which often leads to the development of redundant CPRs. Second, most CPRs do not get evaluated in an independent external validation study even many years after they are developed. ${ }^{8}$ Third, CPRs evaluated in high quality impact studies are rare. ${ }^{9}$ These CPRs, without independently confirmed external validity and high quality evidence of impact, are unlikely to be recommended by guidelines or integrated in practice software, and therefore gain the trust of clinicians.

Electronic databases were searched and 23 studies were found that assessed the familiarity or use of various cardiovascular CPRs: 12 from European countries, ${ }^{6,10-20}$ six from the US, ${ }^{21-26}$ three from Australia and New Zealand, ${ }^{27-29}$ and two from other countries. ${ }^{30,31}$ These studies showed the familiarity with and use of cardiovascular CPRs varied widely according to specialties and geographic locations. For example, fewer GPs in Europe ${ }^{20}$ and primary care doctors in the US ${ }^{26}$ reported using $\mathrm{CHA}_{2} \mathrm{DS}_{2-}$ VASc score compared with cardiologists. On the other hand, more GPs in Europe reported using HAS-BLED score than primary care doctors in the US. ${ }^{20,26}$

A UK study by Plüddemann et al ${ }^{6}$ evaluated GPs' awareness and use of CPRs for multiple clinical areas. The study included a survey of CPRs for cardiovascular disease risk, stroke, and venous thromboembolism that found the majority of GPs used Framingham risk scores, QRISK scores, and Wells rule for deep vein thrombosis. ${ }^{6}$ However, CPRs assessed in their study were primarily identified from guidelines developed before 2011 and many new CPRs have been published since.

Therefore, a survey was conducted to understand which cardiovascular CPRs are currently recognised and used by GPs in the UK. Furthermore, changes in the GPs' familiarity with and use of cardiovascular CPRs were assessed by comparing the results of the current and 2014 survey by Plüddemann et al. ${ }^{6}$

\section{Method}

The target participants were GPs who were practising medicine in the UK at the time of the survey. Doctors in training, GP registrars, and retired GPs were excluded. Using identical methods to the 2014 survey, ${ }^{6}$ GPs were recruited from doctors.net.uk (https://doctors.net.uk), which is a network of doctors in the UK with $>238000$ members. Doctors.net.uk sent emails with an online link for the study information page to invite GP members who opted to receive information about research participation. The information page outlined the aim of the study, why they were invited, who the researchers were, how long it would take to complete, how data would be stored, and how to raise any concern. For participating, 1000 electronic surfing reward points were offered as an incentive, which is equivalent to 5 GBP. Participants confirmed they were aged $\geq 18$ years, that they had read and understood the information page, and agreed to participate voluntarily by ticking a box before they could proceed to the questionnaire. Each GP could take part in the survey no more than once. To be comparable with the 2014 survey, the study aimed to recruit a convenience sample of 401 GPs stratified by geographic regions (or approximately $0.9 \%$ of GP members from each region). Doctors. net.uk closed the survey in a region once the target sample size for the region was reached.

The questionnaire consisted of three sections (see Supplementary Box S1). The first section included three questions for determining eligibility. The second section contained questions about the familiarity with and use of 19 cardiovascular CPRs. For the familiarity with CPRs, participants were asked to indicate whether: a) the CPR was integrated in electronic health record (EHR); b) they had heard of it; c) they had never heard of it; or d) they were not sure. For the use of CPRs, participants were asked to report whether they used the CPR: a) in most or all relevant cases; b) occasionally; c) rarely; or d) never. The order of CPRs presented to each survey participant was randomised. Participants were also asked to indicate for which specific reasons they used cardiovascular CPRs. The last section consisted of five questions about the demographics of participants. No personal information was 
collected. The questions and available answers were the same as the 2014 survey except for the additional option of 'the CPR was integrated in EHR' for the familiarity question.

Cardiovascular CPRs were selected that were likely to be recognised and used by GPs in the UK (Table 1). First, all CPRs for cardiovascular disease risk, stroke, and venous thromboembolism were included from the 2014 survey for comparability. When a CPR had been updated, the updated versions were chosen. Second, the American College of Cardiology (ACC) and American Heart Association (AHA) pooled cohort equation ${ }^{32}$ and New Zealand Primary Prevention Equations ${ }^{33}$ were included because major guidelines in the $\mathrm{US}^{34}$ and New Zealand ${ }^{35}$ currently recommend them instead of Framingham risk scores and New Zealand tables. Third, any additional cardiovascular CPRs recommended by major UK, ${ }^{36-41}$ European, ${ }^{42-46}$ and World Health Organization ${ }^{47}$ guidelines were included. GPs were also asked to name any other cardiovascular CPRs or CPRs in other clinical areas that they were using.

The characteristics of participants were described using medians and interquartile ranges for continuous variables, and numbers and proportions for categorical variables. Two-sample test of proportions were used to assess the null hypotheses that proportions of GPs unfamiliar with CPRs and proportions of GPs using CPRs are the same between the current and 2014 survey. Because conducting multiple significance tests (11 comparisons for GPs' familiarity with CPRs and 11 comparisons for GPs' use of CPRs) can increase the risk of type I error, the robustness of the results were examined by adjusting $P$ values and confidence intervals $(\mathrm{Cls})$ using the Bonferroni method. ${ }^{48}$ The reasons for using CPRs were presented with numbers and proportions. Stata (version 14) was used for all analyses.

\section{Results}

The survey commenced on 18 June 2019 and concluded on 1 July 2019 when the target sample size of 401 was reached. Characteristics of GPs who participated and their practices were similar between the current and 2014 survey (Table 2). Compared with the 2014 survey, the proportions of GPs unfamiliar with QRISK scores, ABCD scores, CHADS scores, Wells scores for deep vein thrombosis, and Wells scores for pulmonary embolism decreased (Table 3).

The proportions of GPs using CPRs in the 2014 and current survey are presented in Figure 1. For cardiovascular disease risk CPRs, the proportion of GPs using JBS risk calculator, Framingham risk scores, and New Zealand tables decreased, whereas the proportion of GPs using QRISK scores increased (Figure 1A). Among CPRs for stroke and venous thromboembolism, the proportion of GPs using $A B C D$ scores, California scores, CHADS scores, Wells scores for deep vein thrombosis, and Well scores for pulmonary embolism increased (Figure 1B). Five GPs named four other CPRs they were using for stroke and venous thromboembolism but which were not asked about in the survey. They were the Cincinnati Prehospital Stroke Scale (CPSS, also known as FAST) ${ }^{49}(n=2)$, the National Institutes of Health $(\mathrm{NIH})$ Stroke Scale ${ }^{50}(n=1)$, the Pulmonary Embolism Rule-out Criteria (PERC) rule $^{51}(n=1)$, and QStroke score ${ }^{52}(n=1)$.

The frequency of using cardiovascular CPRs is presented in Table 4. Many GPs reported using a CPR in most or all cases when it is integrated into their EHR software. Cardiovascular CPRs most often integrated into EHR software were QRISK scores, ABCD scores, CHADS scores, HAS-BLED score, Wells scores for deep vein thrombosis, and Wells scores for pulmonary embolism. The reported reasons for using CPRs are presented in Table 5.

CPRs in other clinical areas GPs most commonly reported using were the Fracture Risk Assessment Tool (FRAX) $)^{53}(n=24)$, Centor score ${ }^{54}(n=16)$, FeverPAIN score ${ }^{55}(n=16)$, Patient Health Questionnaire-9 $9^{56}(n=10)$, Epworth Sleepiness Scale ${ }^{57}(n=8)$, CRB-65 or CURB-65 ${ }^{58}(n=7)$, Six Item Cognitive Impairment Test ${ }^{59}(n=6)$, Hospital Anxiety and Depression Scale ${ }^{60}(n=6)$, International Prostatism Symptom Score ${ }^{61}(n=6)$, and QCANCER Risk Assessment Tools ${ }^{62}(n=6)$ (data not shown).

\section{Discussion}

\section{Summary}

The present study evaluated which cardiovascular CPRs are currently recognised and used by GPs in the UK. It also assessed how GPs' familiarity with and use of cardiovascular CPRs changed by comparing the results of the current and 2014 survey by Plüddemann et al. ${ }^{6}$ 
Table 1 Clinical prediction rules included in the current and 2014 survey

\begin{tabular}{|c|c|c|}
\hline $\begin{array}{l}\text { CPR included in the } 2014 \\
\text { survey }\end{array}$ & $\begin{array}{l}\text { CPR included in the current } \\
\text { survey }\end{array}$ & Current guideline recommending CPR \\
\hline \multicolumn{3}{|l|}{ Cardiovascular disease risk } \\
\hline JBS2 risk charts or calculator ${ }^{67}$ & JBS3 risk calculator ${ }^{68}$ & $\begin{array}{l}\text { JBS' consensus recommendations for } \\
\text { the prevention of cardiovascular disease } \\
(\mathrm{JBS} 3)^{68}\end{array}$ \\
\hline QRISK or QRISK2 $2^{69,70}$ & QRISK2 or QRISK3 $3^{70,71}$ & $\begin{array}{l}\text { NICE clinical guideline CG181: } \\
\text { Cardiovascular disease: risk assessment } \\
\text { and reduction, including lipid } \\
\text { modification }{ }^{36}\end{array}$ \\
\hline ASSIGN score ${ }^{72}$ & ASSIGN score ${ }^{72}$ & $\begin{array}{l}\text { SIGN 149: Risk estimation and the } \\
\text { prevention of cardiovascular disease }\end{array}$ \\
\hline UKPDS risk engine ${ }^{73}$ & UKPDS risk engine ${ }^{73}$ & - \\
\hline SCORE risk charts ${ }^{74}$ & SCORE risk charts ${ }^{74}$ & $\begin{array}{l}2016 \text { European guidelines on } \\
\text { cardiovascular disease prevention in } \\
\text { clinical practice }^{42}\end{array}$ \\
\hline PROCAM score ${ }^{75}$ & PROCAM score ${ }^{75}$ & - \\
\hline Framingham risk scores ${ }^{76}$ & Framingham risk scores ${ }^{76}$ & 一 \\
\hline - & $\begin{array}{l}\text { ACC/AHA pooled cohort } \\
\text { equation }^{32}\end{array}$ & $\begin{array}{l}2019 \text { ACC/AHA guideline on the primary } \\
\text { prevention of cardiovascular disease }{ }^{34}\end{array}$ \\
\hline New Zealand tables ${ }^{77}$ & New Zealand tables ${ }^{77}$ & 一 \\
\hline- & $\begin{array}{l}\text { New Zealand primary prevention } \\
\text { equations }\end{array}$ & $\begin{array}{l}\text { New Zealand Ministry of Health: } \\
\text { Cardiovascular disease risk assessment } \\
\text { and management for primary care } 2018^{35}\end{array}$ \\
\hline- & WHO/ISH risk prediction charts ${ }^{78}$ & $\begin{array}{l}\text { WHO: Prevention of cardiovascular } \\
\text { disease }\end{array}$ \\
\hline \multicolumn{3}{|c|}{ Stroke and venous thromboembolism ${ }^{a}$} \\
\hline $\mathrm{ABCD}$ or $\mathrm{ABCD}^{2} 79,80$ & $\begin{array}{l}\mathrm{ABCD}^{2}, \mathrm{ABCD}^{3}, \text { or } A B C D^{3}-1 \\
\text { score }^{80,81}\end{array}$ & $\begin{array}{l}\text { NICE clinical guideline CG68: Stroke } \\
\text { and transient ischaemic attack in } \\
\text { over } 16 \text { seconds: diagnosis and initial } \\
\text { management }{ }^{82}\end{array}$ \\
\hline California score ${ }^{83}$ & California score ${ }^{83}$ & - \\
\hline CHADS or $\mathrm{CHADS}_{2}^{84}$ & $\mathrm{CHADS}_{2}$ or $\mathrm{CHA}_{2} \mathrm{DS}_{2}-$ VASc score ${ }^{84,85}$ & $\begin{array}{l}\text { NICE clinical guideline CG180: Atrial } \\
\text { fibrillation: management; }{ }^{38} \text { SIGN 129: } \\
\text { Antithrombotics: indications and } \\
\text { management; }{ }^{39} \text { and } 2016 \text { ESC guidelines } \\
\text { for the management of atrial fibrillation } \\
\text { developed in collaboration with EACTS }\end{array}$ \\
\hline - & HAS-BLED score ${ }^{86}$ & $\begin{array}{l}\text { NICE clinical guideline CG180: Atrial } \\
\text { fibrillation: management }{ }^{38}\end{array}$ \\
\hline $\begin{array}{l}\text { Wells scores for deep vein } \\
\text { thrombosis }^{87}\end{array}$ & $\begin{array}{l}\text { Wells scores for deep vein } \\
\text { thrombosis }\end{array}$ & $\begin{array}{l}\text { NICE clinical guideline CG144: Venous } \\
\text { thromboembolic diseases: diagnosis, } \\
\text { management and thrombophilia } \\
\text { testing; }{ }^{40} \text { and SIGN 122: Prevention } \\
\text { and management of venous } \\
\text { thromboembolism }{ }^{41}\end{array}$ \\
\hline $\begin{array}{l}\text { Wells score for pulmonary } \\
\text { embolism }^{88}\end{array}$ & $\begin{array}{l}\text { Wells scores for pulmonary } \\
\text { embolism }^{88}\end{array}$ & $\begin{array}{l}\text { NICE clinical guideline CG144: Venous } \\
\text { thromboembolic diseases: diagnosis, } \\
\text { management and thrombophilia } \\
\text { testing; }{ }^{40} \text { and SIGN 122: Prevention } \\
\text { and management of venous } \\
\text { thromboembolism }^{41}\end{array}$ \\
\hline
\end{tabular}


Table 1 Continued

\begin{tabular}{|c|c|c|}
\hline $\begin{array}{l}\text { CPR included in the } 2014 \\
\text { survey }\end{array}$ & $\begin{array}{l}\text { CPR included in the current } \\
\text { survey }\end{array}$ & Current guideline recommending CPR \\
\hline- & Geneva or revised Geneva score 89,90 & $\begin{array}{l}2014 \text { ESC guidelines on the diagnosis } \\
\text { and management of acute pulmonary } \\
\text { embolism; }{ }^{44} \text { and SIGN 122: Prevention } \\
\text { and management of venous } \\
\text { thromboembolism }{ }^{41}\end{array}$ \\
\hline- & $\begin{array}{l}\text { Pulmonary Embolism Severity } \\
\text { Index (PESI) or simplified } \\
\text { Pulmonary Embolism Severity } \\
\text { Index (sPESI) }{ }^{91,92}\end{array}$ & $\begin{array}{l}2014 \text { ESC guidelines on the diagnosis } \\
\text { and management of acute pulmonary } \\
\text { embolism }^{45}\end{array}$ \\
\hline
\end{tabular}

aThese CPRs were included under the 'General Medical' category in the 2014 survey. ACC/AHA = American College of Cardiology/Amercian Heart Association. CPR = clinical prediction rule. ESC = European Society of Cardiology. ISH = International Society of Hypertension. JBS = Joint British Societies. NICE = National Institute for Health and Care Excellence. SIGN = Scottish Intercollegiate Guidelines Network. WHO = World Health Organization.

It was found that cardiovascular CPRs recognised and used by the majority of GPs were QRISK scores, ABCD scores, CHADS scores, HAS-BLED score, Wells scores for deep vein thrombosis, and Wells scores for pulmonary embolism. These cardiovascular CPRs were also the CPRs recommended by UK guidelines and most frequently integrated into GPs' EHR software. QRISK scores have become dominant CPRs for cardiovascular disease risk assessment in the UK while the popularity of Framingham risk scores waned. For stroke and venous thromboembolism, substantially more GPs are now using ABCD scores, CHADS scores, Wells scores for deep vein thrombosis, and Wells scores for pulmonary embolism. Therefore, it may be hypothesised that integrating CPRs into national guidelines and their EHR software increase the familiarity with and use of CPRs in practice. GPs used CPRs for cardiovascular disease risk most commonly to guide therapy, comply with clinical guidelines, and inform or educate patients; and CPRs for stroke and venous thromboembolism mainly to guide referral, guide therapy, and aid diagnosis.

\section{Strengths and limitations}

To the authors' knowledge, this is the first study that evaluated changes in the familiarity with and use of CPRs over time in a country. Temporal trends were able to be evaluated by applying the recruitment strategy, sampling method, questionnaire, and analysis equivalent to the ones used in the 2014 survey.

Although the study is potentially subject to increased risk of type I error (spurious significant finding) owing to multiple statistical tests, it was found that almost all the comparisons remained statistically significant after adjusting for multiple testing. Only an apparent increased familiarity with the California score did not remain statistically significant and this did not affect the conclusions.

GPs were recruited from doctors.net.uk for compatibility with the 2014 survey. Although this strategy allowed recruitment of a geographically representative sample of GPs from all UK regions efficiently and gave a direct comparability to the 2014 survey, it prevented the response rate from being calculated. The other drawback that could not be excluded was the possibility that the sample over-represented those interested in the topic. It is also unclear whether findings of the survey are generalisable to all GPs in the UK. Furthermore, the findings may have limited applicability outside of the UK and to CPRs for other clinical areas.

\section{Comparison with existing literature}

It was found that most GPs in the survey were familiar with and used cardiovascular CPRs. This is consistent with findings from other recently conducted surveys that reported the awareness and use of cardiovascular CPRs were high. ${ }^{19,20,26}$ For example, a study published in 2015 found $92.5 \%$ of Irish GPs were aware of a cardiovascular disease risk calculator and $72.8 \%$ of them used it. ${ }^{19}$ On the other hand, studies conducted before 2010 often showed cardiovascular CPRs were infrequently used. ${ }^{10,12,14,21,22,31}$ For example, a US national survey from 2006 found only $17 \%$ of family physicians used a coronary heart disease risk calculator. ${ }^{22}$

Common reasons for using cardiovascular CPRs in the existing literature were to educate patients, ${ }^{17,19,27}$ motivate lifestyle changes, ${ }^{16,19,27}$ guide drug therapy, ${ }^{16,19,23,27}$ and establish treatment 
Table 2 Characteristics of GPs and their practices, $N=401$

\begin{tabular}{|c|c|c|}
\hline Characteristic & 2014 survey, $n(\%)^{a}$ & 2019 survey, n (\%) \\
\hline \multicolumn{3}{|l|}{ Sex } \\
\hline Male & $243(60.6)$ & $245(61.1)$ \\
\hline Female & $158(39.4)$ & $153(38.2)$ \\
\hline Other & - & $3(0.7)$ \\
\hline Median year qualified (IQR) & 1995 (1986-2000) & 1998 (1991-2004) \\
\hline \multicolumn{3}{|l|}{ Type of GP } \\
\hline GP partner or principal & $267(66.6)$ & $222(55.4)$ \\
\hline Salaried GP & $95(23.7)$ & $117(29.2)$ \\
\hline Locum GP & $32(8.0)$ & $54(13.5)$ \\
\hline Sessional GP & $4(1.0)$ & $8(2.0)$ \\
\hline Retainer GP & $3(0.7)$ & $0(0.0)$ \\
\hline \multicolumn{3}{|l|}{ Academic role ${ }^{c}$} \\
\hline Research only & - & $7(1.7)$ \\
\hline Teaching only & - & $197(49.1)$ \\
\hline Both research and teaching & - & $38(9.5)$ \\
\hline Neither & - & $159(39.7)$ \\
\hline Median practice size ${ }^{d}(I Q R)$ & $6 \mathrm{GPs}$ (4 to 7 ) & $6 \mathrm{GPs}$ (4 to 8$)$ \\
\hline \multicolumn{3}{|l|}{ Practice type } \\
\hline Urban area & $150(37.4)$ & $161(40.1)$ \\
\hline Suburban area & $119(29.7)$ & $105(26.2)$ \\
\hline Semi-rural area & $87(21.7)$ & $89(22.2)$ \\
\hline Rural area & $45(11.2)$ & $46(11.5)$ \\
\hline \multicolumn{3}{|l|}{ Region $^{e}$} \\
\hline England & $323(80.5)$ & $335(83.5)$ \\
\hline East of England & $35(8.7)$ & $34(8.5)$ \\
\hline London & $48(12.0)$ & $56(14.0)$ \\
\hline East Midlands & $25(6.2)$ & $26(6.5)$ \\
\hline West Midlands & $33(8.2)$ & $36(9.0)$ \\
\hline North East & $17(4.2)$ & $16(4.0)$ \\
\hline Yorkshire \& Humber & $33(8.2)$ & $33(8.2)$ \\
\hline North West & $43(10.7)$ & $43(10.7)$ \\
\hline South East & $51(12.7)$ & $54(13.5)$ \\
\hline South West & $38(9.5)$ & $37(9.2)$ \\
\hline Scotland & $48(12.0)$ & $38(9.5)$ \\
\hline Wales & $18(4.5)$ & $17(4.2)$ \\
\hline Northern Ireland & $12(3.0)$ & $11(2.7)$ \\
\hline
\end{tabular}

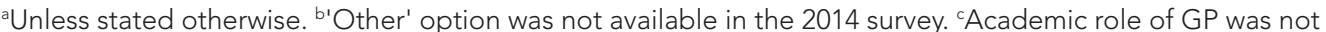
included in the 2014 survey. ${ }^{\mathrm{d}} 16$ of 401 GPs did not know practice size in the current survey. ${ }^{~}$ England was further stratified by the strategic health authority regions of the NHS. IQR = interquartile range. 
Table 3 GPs unfamiliar with clinical prediction rules (CPRs): GPs who had never heard of or who were not sure whether they heard of respective CPRs, $N=401$

\begin{tabular}{|c|c|c|c|c|c|c|c|c|c|c|c|}
\hline \multirow[b]{2}{*}{ CPR } & \multicolumn{3}{|c|}{2014 survey, $n$ (\%) } & \multicolumn{3}{|c|}{2019 survey, n (\%) } & \multicolumn{5}{|c|}{ Change in proportion of GPs unfamiliar to CPR } \\
\hline & $\begin{array}{l}\text { 'Never } \\
\text { heard of' }\end{array}$ & 'Not sure' & Total & $\begin{array}{l}\text { 'Never } \\
\text { heard of' }\end{array}$ & $\begin{array}{l}\text { 'Not } \\
\text { sure' }\end{array}$ & Total & $\%$ & $95 \% \mathrm{Cl}$ & $P$ value & $99.5 \% \mathrm{Cl}^{\mathrm{a}}$ & $P$ value $^{a}$ \\
\hline \multicolumn{12}{|c|}{ Cardiovascular disease } \\
\hline $\begin{array}{l}\text { JBS3 risk } \\
\text { calculator }\end{array}$ & $19(4.7)$ & $8(2.0)$ & $27(6.7)$ & $122(30.4)$ & $28(7.0)$ & $150(37.4)$ & 30.7 & 25.3 to 36.0 & $<0.001$ & 23.0 to 38.3 & $<0.011$ \\
\hline $\begin{array}{l}\text { QRISK2 or } \\
\text { QRISK3 }^{c}\end{array}$ & $64(16.0)$ & $24(6.0)$ & $88(21.9)$ & $4(1.0)$ & $0(0.0)$ & $4(1.0)$ & -20.9 & $\begin{array}{c}-25.1 \text { to } \\
-16.8\end{array}$ & $<0.001$ & $\begin{array}{c}-26.9 \text { to } \\
-15.0\end{array}$ & $<0.011$ \\
\hline ASSIGN score & - & - & - & $222(55.4)$ & $32(8.0)$ & $254(63.3)$ & - & - & - & - & - \\
\hline $\begin{array}{l}\text { UKPDS risk } \\
\text { engine }\end{array}$ & - & - & - & $140(34.9)$ & $23(5.7)$ & $163(40.6)$ & - & - & - & - & - \\
\hline SCORE risk charts & $265(66.1)$ & $67(16.7)$ & $332(82.8)$ & $273(68.1)$ & $37(9.2)$ & $310(77.3)$ & -5.5 & -11.0 to 0.0 & 0.052 & -13.4 to 2.4 & 0.571 \\
\hline PROCAM score & $328(81.8)$ & $50(12.5)$ & $378(94.3)$ & $337(84.0)$ & $36(9.0)$ & $373(93.0)$ & -1.2 & -4.6 to 2.1 & 0.469 & -6.1 to 3.6 & 1.000 \\
\hline $\begin{array}{l}\text { Framingham risk } \\
\text { scores }\end{array}$ & $4(1.0)$ & $2(0.5)$ & $6(1.5)$ & $18(4.5)$ & $4(1.0)$ & $22(5.5)$ & 4.0 & 1.5 to 6.5 & 0.002 & 0.4 to 7.6 & 0.023 \\
\hline $\begin{array}{l}\text { ACC/AHA pooled } \\
\text { cohort equation }^{d}\end{array}$ & - & - & - & $347(86.5)$ & $30(7.5)$ & $377(94.0)$ & - & - & - & - & - \\
\hline $\begin{array}{l}\text { New Zealand } \\
\text { tables }\end{array}$ & $249(62.1)$ & $64(16.0)$ & $313(78.1)$ & $328(81.8)$ & $26(6.5)$ & $354(88.3)$ & 10.2 & 5.1 to 15.4 & $<0.001$ & 2.9 to 17.6 & $<0.011$ \\
\hline $\begin{array}{l}\text { New Zealand } \\
\text { primary } \\
\text { prevention } \\
\text { equations }^{\text {d }}\end{array}$ & - & - & - & $352(87.8)$ & $28(7.0)$ & $380(94.8)$ & - & - & - & - & - \\
\hline $\begin{array}{l}\text { WHO/ISH risk } \\
\text { prediction charts }^{d}\end{array}$ & - & - & - & $262(65.3)$ & $33(8.2)$ & $295(73.6)$ & - & - & - & - & - \\
\hline \multicolumn{12}{|c|}{ Stroke and venous thromboembolism } \\
\hline $\begin{array}{l}A B C D^{2}, A B C D^{3} \text { or } \\
A B C D^{3}-1 \text { score }\end{array}$ & $128(31.9)$ & $45(11.2)$ & $173(43.1)$ & $98(24.4)$ & $14(3.5)$ & $112(27.9)$ & -15.2 & $\begin{array}{c}-21.8 \text { to } \\
-8.7\end{array}$ & $<0.001$ & $\begin{array}{c}-24.6 \text { to } \\
-5.8\end{array}$ & $<0.011$ \\
\hline California score & $336(83.8)$ & $50(12.5)$ & $386(96.3)$ & $341(85.0)$ & $31(7.7)$ & $372(92.8)$ & -3.5 & -6.6 to -0.3 & 0.030 & -8.0 to 1.0 & 0.329 \\
\hline $\begin{array}{l}\mathrm{CHADS}_{2} \text { or } \\
\mathrm{CHA}_{2} \mathrm{DS}_{2} \text {-VASc } \\
\text { score }^{f}\end{array}$ & $160(39.9)$ & $48(12.0)$ & $208(51.9)$ & $5(1.2)$ & $2(0.5)$ & $7(1.7)$ & -50.1 & $\begin{array}{c}-55.2 \text { to } \\
-45.1\end{array}$ & $<0.001$ & $\begin{array}{c}-57.4 \text { to } \\
-42.9\end{array}$ & $<0.011$ \\
\hline HAS-BLED score ${ }^{d}$ & - & - & - & $12(3.0)$ & $4(1.0)$ & $16(4.0)$ & - & - & - & - & - \\
\hline $\begin{array}{l}\text { Wells scores } \\
\text { for deep vein } \\
\text { thrombosis }\end{array}$ & $109(27.2)$ & $30(7.5)$ & $139(34.7)$ & $12(3.0)$ & $5(1.2)$ & $17(4.2)$ & -30.4 & $\begin{array}{c}-35.5 \text { to } \\
-25.4\end{array}$ & $<0.001$ & $\begin{array}{c}-37.7 \text { to } \\
-23.2\end{array}$ & $<0.011$ \\
\hline $\begin{array}{l}\text { Wells scores } \\
\text { for pulmonary } \\
\text { embolism }\end{array}$ & $169(42.1)$ & $59(14.7)$ & $228(56.9)$ & $31(7.7)$ & $21(5.2)$ & $52(13.0)$ & -43.9 & $\begin{array}{c}-49.7 \text { to } \\
-38.0\end{array}$ & $<0.001$ & $\begin{array}{l}-52.3 \text { to } \\
-35.5\end{array}$ & $<0.011$ \\
\hline $\begin{array}{l}\text { Geneva or } \\
\text { revised Geneva } \\
\text { score }^{d}\end{array}$ & - & - & - & 315 (78.6) & $32(8.0)$ & 347 (86.5) & - & - & - & - & - \\
\hline $\begin{array}{l}\text { PESI or simplified } \\
\text { PESI }\end{array}$ & - & - & - & 318 (79.3) & $30(7.5)$ & $348(86.8)$ & - & - & - & - & - \\
\hline
\end{tabular}

goal. ${ }^{19,27}$ In addition to these, GPs in the present study frequently used cardiovascular CPRs to comply with guidelines or the Quality and Outcomes Framework, which might be unique for GPs in the UK. The National Institute for Health and Care Excellence (NICE) guideline published in 2008 advised using Framingham risk score to assess cardiovascular risk. ${ }^{63}$ After external validation studies in the UK showed QRISK scores consistently performed better than Framingham risk score, ${ }^{64-66}$ QRISK2 was recommended by the 2014 NICE guideline. ${ }^{36}$ This shift in guideline recommendation might explain notable changes in the use of CPRs for assessing the risk of cardiovascular disease. Similarly, most GPs in the present survey used CHADS scores and HAS-BLED score that were first recommended by the 2012 Scottish Intercollegiate Guidelines Network ${ }^{39}$ and 2014 NICE guideline. ${ }^{38}$ 


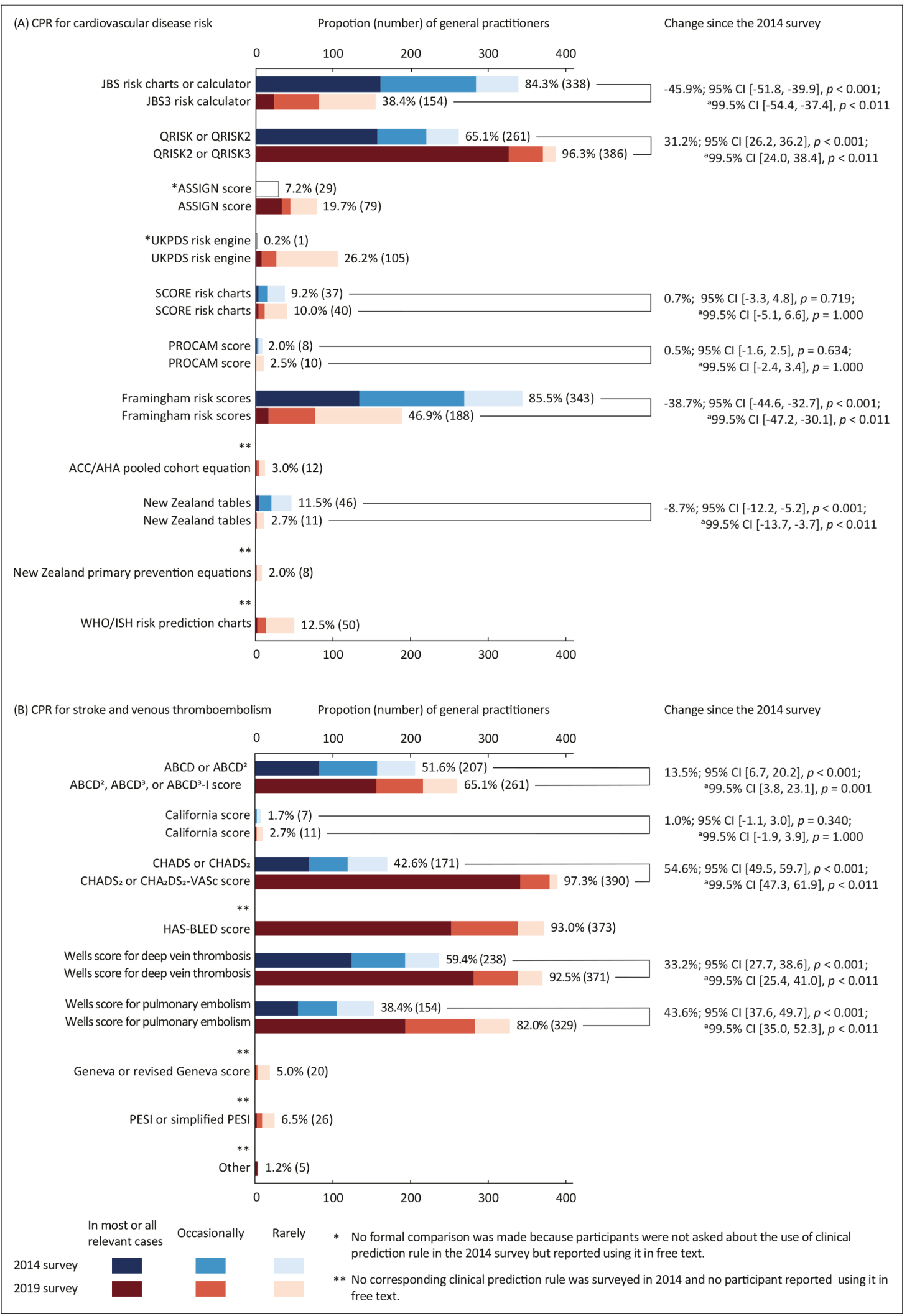

Figure 1 The proportion of GPs using clinical prediction rules for A) cardiovascular disease risk and B) venous thromboembolism in the 2014 and current

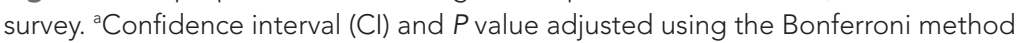

\section{Implications for research and practice}


Table 4 Frequency of using cardiovascular clinical prediction rules by all GPs who participated and GPs who reported that CPR was integrated in electronic health record

\begin{tabular}{|c|c|c|c|c|c|c|c|c|c|c|}
\hline \multirow[b]{3}{*}{ CPR } & \multirow[b]{3}{*}{ GPs, $n$} & \multicolumn{4}{|c|}{ All GPs who participated in the survey } & \multicolumn{5}{|c|}{$\begin{array}{l}\text { GPs who reported that 'CPR was integrated in electronic } \\
\text { health record' }\end{array}$} \\
\hline & & \multicolumn{3}{|c|}{ Use CPR, $n$ (\%) } & \multirow{2}{*}{$\begin{array}{c}\text { Do not } \\
\text { use CPR, } \\
n(\%)\end{array}$} & \multirow[b]{2}{*}{ GPs, $n$} & \multicolumn{3}{|c|}{ Use CPR, $n$ (\%) } & \multirow[b]{2}{*}{$\begin{array}{c}\text { Do not use CPR, } \\
n(\%)\end{array}$} \\
\hline & & $\begin{array}{l}\text { Most or all } \\
\text { cases }\end{array}$ & Occasionally & Rarely & & & $\begin{array}{l}\text { Most or all } \\
\text { cases }\end{array}$ & Occasionally & Rarely & \\
\hline \multicolumn{11}{|l|}{$\begin{array}{l}\text { Cardiovascular } \\
\text { disease }\end{array}$} \\
\hline $\begin{array}{l}\text { JBS3 risk } \\
\text { calculator }\end{array}$ & 401 & $23(5.7)$ & $58(14.5)$ & $73(18.2)$ & $247(61.6)$ & 43 & $12(27.9)$ & $16(37.2)$ & $9(20.9)$ & $6(14.0)$ \\
\hline $\begin{array}{l}\text { QRISK2 or } \\
\text { QRISK3 }\end{array}$ & 401 & $325(81.0)$ & $44(11.0)$ & $17(4.2)$ & $15(3.7)$ & 280 & $257(91.8)$ & $21(7.5)$ & $1(0.4)$ & $1(0.4)$ \\
\hline ASSIGN score & 401 & $33(8.2)$ & $11(2.7)$ & $35(8.7)$ & $322(80.3)$ & 24 & $21(87.5)$ & $2(8.3)$ & $1(4.2)$ & $0(0.0)$ \\
\hline $\begin{array}{l}\text { UKPDS risk } \\
\text { engine }\end{array}$ & 401 & $7(1.7)$ & $19(4.7)$ & $79(19.7)$ & $296(73.8)$ & 14 & $3(21.4)$ & $3(21.4)$ & $4(28.6)$ & $4(28.6)$ \\
\hline $\begin{array}{l}\text { SCORE risk } \\
\text { charts }\end{array}$ & 401 & $3(0.7)$ & $8(2.0)$ & $29(7.2)$ & $361(90.0)$ & 3 & $1(33.3)$ & $1(33.3)$ & $1(33.3)$ & $0(0.0)$ \\
\hline PROCAM score & 401 & $0(0.0)$ & $0(0.0)$ & $10(2.5)$ & 391 (97.5) & 2 & $0(0.0)$ & $0(0.0)$ & $0(0.0)$ & $2(100)$ \\
\hline $\begin{array}{l}\text { Framingham risk } \\
\text { scores }\end{array}$ & 401 & $16(4.0)$ & $60(15.0)$ & $112(27.9)$ & $213(53.1)$ & 56 & $7(12.5)$ & 19 (33.9) & 19 (33.9) & $11(19.6)$ \\
\hline $\begin{array}{l}\text { ACC/AHA } \\
\text { pooled cohort } \\
\text { equation }\end{array}$ & 401 & $1(0.2)$ & $3(0.7)$ & $8(2.0)$ & $389(97.0)$ & 1 & $1(100)$ & $0(0.0)$ & $0(0.0)$ & $0(0.0)$ \\
\hline $\begin{array}{l}\text { New Zealand } \\
\text { tables }\end{array}$ & 401 & $1(0.2)$ & $0(0.0)$ & $10(2.5)$ & $390(97.3)$ & 1 & $1(100)$ & $0(0.0)$ & $0(0.0)$ & $0(0.0)$ \\
\hline $\begin{array}{l}\text { New Zealand } \\
\text { primary } \\
\text { prevention } \\
\text { equation }\end{array}$ & 401 & $1(0.2)$ & $0(0.0)$ & $7(1.7)$ & $393(98.0)$ & 1 & $1(100)$ & $0(0.0)$ & $0(0.0)$ & $0(0.0)$ \\
\hline $\begin{array}{l}\text { WHO/ISH risk } \\
\text { prediction charts }\end{array}$ & 401 & $2(0.5)$ & $11(2.7)$ & $37(9.2)$ & $351(87.5)$ & 2 & $0(0.0)$ & $1(50.0)$ & $1(50.0)$ & $0(0.0)$ \\
\hline \multicolumn{11}{|l|}{$\begin{array}{l}\text { Stroke and venous } \\
\text { thromboembolism }\end{array}$} \\
\hline $\begin{array}{l}A B C D^{2}, A B C D^{3} \text { or } \\
A B C D^{3}-1 \text { score }\end{array}$ & 401 & $156(38.9)$ & $61(15.2)$ & $44(11.0)$ & 140 (34.9) & 107 & 81 (75.7) & $21(19.6)$ & $3(2.8)$ & $2(1.9)$ \\
\hline California score & 401 & $1(0.2)$ & $2(0.5)$ & $8(2.0)$ & $390(97.3)$ & 1 & $0(0.0)$ & $0(0.0)$ & $0(0.0)$ & $1(100)$ \\
\hline $\begin{array}{l}\mathrm{CHADS}_{2} \text { or } \\
\mathrm{CHA}_{2} \mathrm{DS}_{2}-\mathrm{VASc} \\
\text { score }\end{array}$ & 401 & $341(85.0)$ & $39(9.7)$ & $10(2.5)$ & $11(2.7)$ & 273 & $255(93.4)$ & $13(4.8)$ & $3(1.1)$ & $2(0.7)$ \\
\hline HAS-BLED score & 401 & $252(62.8)$ & 87 (21.7) & $34(8.5)$ & $28(7.0)$ & 207 & $168(81.2)$ & $29(14.0)$ & $10(4.8)$ & $0(0.0)$ \\
\hline $\begin{array}{l}\text { Wells scores } \\
\text { for deep vein } \\
\text { thrombosis }\end{array}$ & 401 & $281(70.1)$ & $58(14.5)$ & $32(8.0)$ & $30(7.5)$ & 184 & $166(90.2)$ & $14(7.6)$ & $1(0.5)$ & $3(1.6)$ \\
\hline $\begin{array}{l}\text { Wells scores } \\
\text { for pulmonary } \\
\text { embolism }\end{array}$ & 401 & $193(48.1)$ & $91(22.7)$ & 45 (11.2) & $72(18.0)$ & 153 & 112 (73.2) & $29(19.0)$ & $9(5.9)$ & $3(2.0)$ \\
\hline $\begin{array}{l}\text { Geneva or } \\
\text { revised Geneva } \\
\text { score }\end{array}$ & 401 & $1(0.2)$ & $3(0.7)$ & $16(4.0)$ & $381(95.0)$ & 1 & $0(0.0)$ & $0(0.0)$ & $1(100)$ & $0(0.0)$ \\
\hline $\begin{array}{l}\text { PESI or simplified } \\
\text { PESI }\end{array}$ & 401 & $2(0.5)$ & $8(2.0)$ & $16(4.0)$ & 375 (93.5) & 3 & $1(33.3)$ & 1 (33.3) & $1(33.3)$ & $0(0.0)$ \\
\hline
\end{tabular}

The study by Plüddemann et al concluded GPs' lack of familiarity was one of the reasons for not using CPRs in practice. Findings of the present study suggest that integrating CPRs into national guidelines and EHR software might be important factors for increasing GPs' familiarity with and use of CPRs. Conducting an international survey in countries where guidelines recommend different CPRs and where EHR software has a varying degree of CPR integrations might be useful in assessing these associations. Ultimately, the hypotheses could be tested by interrupted time-series studies and 
Table 5 GPs reporting respective reasons for using clinical prediction rules, $N=401$

\begin{tabular}{|c|c|c|c|c|}
\hline & \multicolumn{2}{|c|}{2014 survey, n (\%) } & \multicolumn{2}{|c|}{2019 survey, n (\%) } \\
\hline & $\begin{array}{l}\text { Cardiovascular } \\
\text { disease risk }\end{array}$ & $\begin{array}{l}\text { Stroke and venous } \\
\text { thromboembolism }\end{array}$ & $\begin{array}{l}\text { Cardiovascular } \\
\text { disease risk }\end{array}$ & $\begin{array}{l}\text { Stroke and venous } \\
\text { thromboembolism }\end{array}$ \\
\hline $\begin{array}{l}\text { Use clinical prediction } \\
\text { rule }\end{array}$ & 395 (98.5) & $328(81.8)$ & 399 (99.5) & 398 (99.3) \\
\hline To aid diagnosis & $143(35.7)$ & $219(54.6)$ & $145(36.2)$ & $273(68.1)$ \\
\hline $\begin{array}{l}\text { To assess disease } \\
\text { severity }\end{array}$ & $191(47.6)$ & $142(35.4)$ & $163(40.6)$ & $141(35.2)$ \\
\hline To guide therapy & $336(83.8)$ & $188(46.9)$ & $363(90.5)$ & $278(69.3)$ \\
\hline To guide referral & $89(22.2)$ & $218(54.4)$ & 95 (23.7) & $284(70.8)$ \\
\hline $\begin{array}{l}\text { To comply with } \\
\text { clinical guidelines or } \\
\text { Quality and Outcomes } \\
\text { Framework (QOF) }\end{array}$ & $267(66.6)$ & $106(26.4)$ & $253(63.1)$ & $220(54.9)$ \\
\hline $\begin{array}{l}\text { To inform or educate } \\
\text { patients }\end{array}$ & $220(54.9)$ & 75 (18.7) & $220(54.9)$ & $137(34.2)$ \\
\hline $\begin{array}{l}\text { Automatically } \\
\text { generated by practice } \\
\text { software }\end{array}$ & $106(26.4)$ & $19(4.7)$ & $67(16.7)$ & $52(13.0)$ \\
\hline Other & $1(0.2)$ & $3(0.7)$ & $2(0.5)$ & $3(0.7)$ \\
\hline $\begin{array}{l}\text { Do not use clinical } \\
\text { prediction rule }\end{array}$ & $6(1.5)$ & 73 (18.2) & $2(0.5)$ & $3(0.7)$ \\
\hline
\end{tabular}

comparisons between countries with different guidelines or institutions with different CPRs integrated in EHR software.

\section{Funding}

This study was funded by the National Institute for Health Research (NIHR) Collaboration for Leadership in Applied Health Research and Care Oxford. RP acknowledges part-funding from the NIHR Oxford Biomedical Research Centre, the NIHR Oxford and Thames Valley Applied Research Collaborative (ARC), NIHR Oxford Medtech and In-Vitro Diagnostics Co-operative and the Oxford Martin School and part-funding from the National Institute for Health Research (NIHR Programme Grant for Applied Research).

\section{Ethical approval}

The Medical Sciences Interdivisional Research Ethics Committee of the University of Oxford (MS IDREC) conducted an ethical review and approved the study (Reference: R63716/RE001).

\section{Provenance}

Freely submitted; externally peer reviewed.

\section{Acknowledgements}

The authors are grateful to Dr Annette Plüddemann for providing guidance in planning and conducting this study.

\section{References}

1. Steel N, Ford JA, Newton JN, et al. Changes in health in the countries of the UK and 150 English local authority areas 1990-2016: a systematic analysis for the global burden of disease study 2016. Lancet 2018; 392(10158): 1647-1661. DOI: https://doi.org/10.1016/S0140-6736(18)32207-4

2. Collins DRJ, Tompson AC, Onakpoya IJ, et al. Global cardiovascular risk assessment in the primary prevention of cardiovascular disease in adults: systematic review of systematic reviews. BMJ Open 2017; 7(3): e013650. DOI: https://doi.org/10.1136/bmjopen-2016-013650 
3. Goodacre S, Sampson F, Stevenson M, et al. Measurement of the clinical and cost-effectiveness of non-invasive diagnostic testing strategies for deep vein thrombosis. Health Technol Assess 2006; 10(15): 1-168. DOI: https:// doi.org/10.3310/hta10150

4. Keogh C, Wallace E, O'Brien KK, et al. Developing an international register of clinical prediction rules for use in primary care: a descriptive analysis. Ann Fam Med 2014; 12(4): 359-366. DOI: https://doi.org/10.1370/afm.1640

5. Damen JAAG, Hooft L, Schuit E, et al. Prediction models for cardiovascular disease risk in the general population: systematic review. BMJ 2016; 353: i2416. DOI: https://doi.org/10.1136/bmj.i2416

6. Plüddemann A, Wallace E, Bankhead C, et al. Clinical prediction rules in practice: review of clinical guidelines and survey of GPs. Br J Gen Pract 2014; 64(621): e233-e242. DOI: https://doi.org/10.3399/bjgp14X677860

7. Ban J-W, Wallace E, Stevens R, et al. Why do authors derive new cardiovascular clinical prediction rules in the presence of existing rules? A mixed methods study. PLoS One 2017; 12(6): e0179102. DOI: https://doi.org/10. 1371/journal.pone.0179102

8. Ban J-W, Stevens R, Perera R. Predictors for independent external validation of cardiovascular risk clinical prediction rules: COX proportional hazards regression analyses. Diagn Progn Res 2018; 2(1): 3. DOI: https://doi. org/10.1186/s41512-018-0025-6

9. Ban J-W. Design, methods, and reporting of studies evaluating impact of cardiovascular clinical prediction rules: a systematic review. BMJ Evid Based Med 2019; 24(Suppl 1): A12.

10. Thomsen TF, Jørgensen $\mathrm{T}$, Ibsen $\mathrm{H}$, et al. Assessment of coronary risk in general practice in relation to the use of guidelines: a survey in Denmark. Prev Med 2001; 33(4): 300-304. DOI: https://doi.org/10.1006/pmed.2001.0887

11. Hobbs FDR, Erhardt L. Acceptance of guideline recommendations and perceived implementation of coronary heart disease prevention among primary care physicians in five European countries: the reassessing European attitudes about cardiovascular treatment (react) survey. Fam Pract 2002; 19(6): 596-604. DOI: https://doi.org/10.1093/ fampra/19.6.596

12. De Muylder R, Lorant V, Paulus D, et al. Obstacles to cardiovascular prevention in general practice. Acta Cardiol 2004; 59(2): 119-125. DOI: https://doi.org/10.2143/AC.59.2.2005165

13. Bonnevie $L$, Thomsen $T$, Jørgensen $T$. The use of computerized decision support systems in preventive cardiology — principal results from the national PRECARD survey in Denmark. Eur J Cardiovasc Prev Rehabil 2005; 12(1): 52-55.

14. Eichler K, Zoller M, Tschudi $\mathrm{P}$, et al. Barriers to apply cardiovascular prediction rules in primary care: a postal survey. BMC Fam Pract 2007; 8(1): 1. DOI: https://doi.org/10.1186/1471-2296-8-1

15. Müller-Riemenschneider F, Holmberg C, Rieckmann N, et al. Barriers to routine risk-score use for healthy primary care patients: survey and qualitative study. Arch Intern Med 2010; 170(8): 719-724. DOI: https://doi.org/10.1001/ archinternmed.2010.66

16. Dallongeville J, Banegas JR, Tubach F, et al. Survey of physicians' practices in the control of cardiovascular risk factors: the EURIKA study. Eur J Prev Cardiol 2012; 19(3): 541-550. DOI: https://doi.org/10.1177/ 1741826711407705

17. Elustondo SG, Aguado PN, de La Rasilla Cooper CG, et al. Cardiovascular risk tables: opinion and degree of use of primary care doctors from Madrid, Spain. J Eval Clin Pract 2013; 19(1): 148-152. DOI: https://doi.org/10.1111/j. 1365-2753.2011.01785.x

18. Sarazin M, Chiappe SG, Kasprzyk M, et al. A survey of French general practitioners and a qualitative study on their use and assessment of predictive clinical scores. Int J Gen Med 2013; 6: 419-426. DOI: https://doi.org/10.2147/ IJGM.S39022

19. Byrne D, O'Connor L, Jennings $S$, et al. A survey of GPs awareness and use of risk assessment tools and cardiovascular disease prevention guidelines. Ir Med J 2015; 108(7): 204-207.

20. Heidbuchel H, Dagres N, Antz M, et al. Major knowledge gaps and system barriers to guideline implementation among European physicians treating patients with atrial fibrillation: a European Society of Cardiology international educational needs assessment. Europace 2018; 20(12): 1919-1928. DOI: https://doi.org/10.1093/europace/euy039

21. Pearson SD, Goldman L, Garcia TB, et al. Physician response to a prediction rule for the triage of emergency department patients with chest pain. J Gen Intern Med 1994; 9(5): 241-247. DOI: https://doi.org/10.1007/ BF02599648

22. Eaton CB, Galliher JM, McBride PE, et al. Family physician's knowledge, beliefs, and self-reported practice patterns regarding hyperlipidemia: a national research network (NRN) survey. J Am Board Fam Med 2006; 19(1): 46-53. DOI: https://doi.org/10.3122/jabfm.19.1.46

23. Shillinglaw B, Viera AJ, Edwards T, et al. Use of global coronary heart disease risk assessment in practice: a crosssectional survey of a sample of U.S. physicians. BMC Health Serv Res 2012; 12: 20. DOI: https://doi.org/10.1186/ 1472-6963-12-20

24. Pokharel $Y$, Steinberg L, Chan W, et al. Case-Based educational intervention to assess change in providers' knowledge and attitudes towards the 2013 American College of Cardiology/American Heart Association cholesterol management guideline. Atherosclerosis 2016; 246: 115-120. DOI: https://doi.org/10.1016/j. atherosclerosis.2015.12.044

25. Wu X, Malhotra A, Forman HP, et al. The use of high-risk criteria in screening patients for blunt cerebrovascular injury: a survey. Acad Radiol 2017; 24(4): 456-461. DOI: https://doi.org/10.1016/j.acra.2016.11.010

26. Amroze A, Mazor K, Crawford S, et al. Survey of confidence in use of stroke and bleeding risk calculators knowledge of anticoagulants, and comfort with prescription of anticoagulation in challenging scenarios: SUPPORTAF II study. J Thromb Thrombolysis 2019; 48(4): 629-637. DOI: https://doi.org/10.1007/s11239-019-01950-6

27. Imms A, Quinn S, Nelson M. General practitioners' use of cardiovascular risk calculators. Aust Fam Physician 2010 39(1-2): 57-60. 
28. Ferguson $\mathrm{C}$, Inglis $\mathrm{SC}$, Newton PJ, et al. Education and practice gaps on atrial fibrillation and anticoagulation: a survey of cardiovascular nurses. BMC Med Educ 2016; 16(1): 9. DOI: https://doi.org/10.1186/s12909-015-0504-1

29. Ferguson C, Hickman LD, Phillips J, et al. An mHealth intervention to improve nurses' atrial fibrillation and anticoagulation knowledge and practice: the EVICOAG study. Eur J Cardiovasc Nurs 2019; 18(1): 7-15. DOI: https://doi.org/10.1177/1474515118793051

30. Kesieme EB, Arekhandia BJ, Inuwa IM, et al. Knowledge and practice of prophylaxis of deep venous thrombosis: a survey among Nigerian surgeons. Niger J Clin Pract 2016; 19(2): 170-174. DOI: https://doi.org/10.4103/11193077.175961

31. Sposito AC, Ramires JAF, Jukema JW, et al. Physicians' attitudes and adherence to use of risk scores for primary prevention of cardiovascular disease: cross-sectional survey in three world regions. Curr Med Res Opin 2009; 25(5): 1171-1178. DOI: https://doi.org/10.1185/03007990902846423

32. Goff DC, Lloyd-Jones DM, Bennett G, et al. 2013 ACC/AHA guideline on the assessment of cardiovascular risk: a report of the American College of Cardiology/American Heart Association Task force on practice guidelines. J Am Coll Cardiol 2014; 63(25 Pt B): 2935. DOI: https://doi.org/10.1016/j.jacc.2013.11.005

33. Pylypchuk R, Wells S, Kerr A, et al. Cardiovascular disease risk prediction equations in 400000 primary care patients in New Zealand: a derivation and validation study. Lancet 2018; 391(10133): 1897-1907. DOI: https://doi. org/10.1016/S0140-6736(18)30664-0

34. Arnett DK, Blumenthal RS, Albert MA, et al. 2019 ACC/AHA guideline on the primary prevention of cardiovascular disease: a report of the American College of Cardiology/American Heart Association Task force on clinical practice guidelines. Circulation 2019; 140(11): e596-e646. DOI: https://doi.org/10.1161/CIR.0000000000000678

35. Ministry of Health. Cardiovascular disease risk assessment and management for primary care. 2018; https://www. health.govt.nz/publication/cardiovascular-disease-risk-assessment-and-management-primary-care (accessed 22 Sep 2020).

36. National Institute for Health and Care Excellence. Cardiovascular disease: risk assessment and reduction, including lipid modification. CG181. 2014; https://www.nice.org.uk/guidance/cg181 (accessed 22 Sep 2020).

37. Scottish Intercollegiate Guidelines Network. Risk estimation and the prevention of cardiovascular disease. 2017; https://www.sign.ac.uk/assets/sign149.pdf (accessed 22 Sep 2020).

38. National Institute for Health and Care Excellence. Atrial fibrillation: management. CG180. 2014; https://www.nice. org.uk/guidance/cg180 (accessed 22 Sep 2020).

39. Scottish Intercollegiate Guidelines Network. Antithrombotics: indications and management. 2012; https://www. sign.ac.uk/our-guidelines/antithrombotics-indications-and-management (accessed 22 Sep 2020).

40. National Institute for Health and Care Excellence. Venous thromboembolic diseases: diagnosis, management and thrombophilia testing. CG144. 2012; https://www.nice.org.uk/guidance/cg144 (accessed 22 Sep 2020).

41. Scottish Intercollegiate Guidelines Network. Prevention and management of venous thromboembolism. 2010; https://www.sign.ac.uk/media/1060/sign122.pdf (accessed 22 Sep 2020).

42. Piepoli MF, Hoes AW, Agewall S, et al. 2016 European guidelines on cardiovascular disease prevention in clinical practice: The Sixth Joint Task Force of the European Society of Cardiology and other societies on cardiovascular disease prevention in clinical practice (constituted by representatives of 10 societies and by invited experts) developed with the special contribution of the European Association for Cardiovascular Prevention \& Rehabilitation (EACPR). Eur Heart J 2016; 37(29): 2315-2381. DOI: https://doi.org/10.1093/eurheartj/ehw106

43. Kirchhof $P$, Benussi $S$, Kotecha D, et al. 2016 ESC guidelines for the management of atrial fibrillation developed in collaboration with EACTS. Eur Heart J 2016; 37(38): 2893-2962. DOI: https://doi.org/10.1093/eurheartj/ehw210

44. Konstantinides SV, Torbicki A, Agnelli G, et al. 2014 ESC guidelines on the diagnosis and management of acute pulmonary embolism. Eur Heart J 2014; 35(43): 3033-3069, 3069a-3069k. DOI: https://doi.org/10.5603/KP.2014. 0211

45. Williams B, Mancia G, Spiering W, et al. 2018 ESC/ESH guidelines for the management of arterial hypertension. Eur Heart J 2018; 39(33): 3021-3104. DOI: https://doi.org/10.1093/eurheartj/ehy339

46. Catapano AL, Graham I, De Backer G, et al. 2016 ESC/EAS guidelines for the management of dyslipidaemias. Eur Heart J 2016; 37(39): 2999-3058. DOI: https://doi.org/10.1093/eurheartj/ehw272

47. World Health Organization. Prevention of cardiovascular disease: guidelines for assessment and management of total cardiovascular risk. 2007; https://apps.who.int/iris/handle/10665/43685 (accessed 22 Sep 2020).

48. Bland JM, Altman DG. Multiple significance tests: the Bonferroni method. BMJ 1995; 310(6973): 170. DOI: https:// doi.org/10.1136/bmj.310.6973.170

49. Kothari R, Hall K, Brott T, et al. Early stroke recognition: developing an out-of-hospital NIH stroke scale. Acad Emerg Med 1997; 4(10): 986-990. DOI: https://doi.org/10.1111/j.1553-2712.1997.tb03665.x

50. Brott T, Adams HP, Olinger CP, et al. Measurements of acute cerebral infarction: a clinical examination scale. Stroke 1989; 20(7): 864-870. DOI: https://doi.org/10.1161/01.STR.20.7.864

51. Kline JA, Mitchell AM, Kabrhel C, et al. Clinical criteria to prevent unnecessary diagnostic testing in emergency department patients with suspected pulmonary embolism. J Thromb Haemost 2004; 2(8): 1247-1255. DOI: https:// doi.org/10.1111/j.1538-7836.2004.00790.x

52. Hippisley-Cox J, Coupland C, Brindle P. Derivation and validation of QStroke score for predicting risk of ischaemic stroke in primary care and comparison with other risk scores: a prospective open cohort study. BMJ 2013; 346 : f2573. DOI: https://doi.org/10.1136/bmj.f2573

53. Kanis JA, Johnell O, Oden A, et al. FRAXTM and the assessment of fracture probability in men and women from the UK. Osteoporos Int 2008; 19(4): 385-397. DOI: https://doi.org/10.1007/s00198-007-0543-5

54. Centor RM, Witherspoon JM, Dalton HP, et al. The diagnosis of strep throat in adults in the emergency room. Med Decis Making 1981; 1(3): 239-246. DOI: https://doi.org/10.1177/0272989X8100100304 
55. Little P, Hobbs FDR, Moore M, et al. Clinical score and rapid antigen detection test to guide antibiotic use for sore throats: randomised controlled trial of prism (primary care streptococcal management). BMJ 2013; 347 : f5806. DOI: https://doi.org/10.1136/bmj.f5806

56. Kroenke K, Spitzer RL, Williams JB. The PHQ-9: validity of a brief depression severity measure. J Gen Intern Med 2001; 16(9): 606-613. DOI: https://doi.org/10.1046/j.1525-1497.2001.016009606.x

57. Johns MW. A new method for measuring daytime sleepiness: the Epworth Sleepiness scale. Sleep 1991; 14(6): 540-545. DOI: https://doi.org/10.1093/sleep/14.6.540

58. Lim WS, van der Eerden MM, Laing R, et al. Defining community acquired pneumonia severity on presentation to hospital: an international derivation and validation study. Thorax 2003; 58(5): 377-382. DOI: https://doi.org/10. 1136/thorax.58.5.377

59. Blessed G, Tomlinson BE, Roth M. The association between quantitative measures of dementia and of senile change in the cerebral grey matter of elderly subjects. Br J Psychiatry 1968; 114(512): 797-811. DOI: https://doi. org/10.1192/bjp.114.512.797

60. Zigmond AS, Snaith RP. The hospital anxiety and depression scale. Acta Psychiatr Scand 1983; 67(6): 361-370. DOI: https://doi.org/10.1111/j.1600-0447.1983.tb09716.x

61. Barry MJ, Fowler FJ, O'leary MP, et al. The American urological association symptom index for benign prostatic hyperplasia. J Urol 2017; 197(2S): S189-S197. DOI: https://doi.org/10.1016/j.juro.2016.10.071

62. Hippisley-Cox J, Coupland C. Development and validation of risk prediction algorithms to estimate future risk of common cancers in men and women: prospective cohort study. BMJ Open 2015; 5(3): e007825. DOI: https://doi. org/10.1136/bmjopen-2015-007825

63. National Institute for Health and Care Excellence. Lipid modification: cardiovascular risk assessment and the modification of blood lipids for the primary and secondary prevention of cardiovascular disease. CG67. 2008; https://www.nice.org.uk/guidance/cg67 (accessed 22 Sep 2020).

64. Collins GS, Altman DG. An independent external validation and evaluation of QRISK cardiovascular risk prediction: a prospective open cohort study. BMJ 2009; 339: b2584. DOI: https://doi.org/10.1136/bmj.b2584

65. Collins GS, Altman DG. An independent and external validation of QRISK2 cardiovascular disease risk score: a prospective open cohort study. BMJ 2010; 340: c2442. DOI: https://doi.org/10.1136/bmj.c2442

66. Collins GS, Altman DG. Predicting the 10 year risk of cardiovascular disease in the United Kingdom: independent and external validation of an updated version of QRISK2. BMJ 2012; 344: e4181. DOI: https://doi.org/10.1136/ bmj.e4181

67. British Cardiac Society, British Hypertension Society, Diabetes UK, et al. JBS 2: Joint British Societies' guidelines on prevention of cardiovascular disease in clinical practice. Heart 2005; 91 Suppl 5(Suppl 5): v1-v52. DOI: https://doi. org/10.1136/hrt.2005.079988

68. JBS3 Board. Joint British Societies' consensus recommendations for the prevention of cardiovascular disease (JBS3). Heart 2014; 100 Suppl 2: ii1-ii67. DOI: https://doi.org/10.1136/heartjnl-2014-305693

69. Hippisley-Cox J, Coupland C, Vinogradova Y, et al. Derivation and validation of QRISK, a new cardiovascular disease risk score for the United Kingdom: prospective open cohort study. BMJ 2007; 335(7611): 136. DOI: https:// doi.org/10.1136/bmj.39261.471806.55

70. Hippisley-Cox J, Coupland C, Vinogradova Y, et al. Predicting cardiovascular risk in England and Wales: prospective derivation and validation of QRISK2. BMJ 2008; 336(7659): 1475-1482. DOI: https://doi.org/10.1136/ bmj.39609.449676.25

71. Hippisley-Cox J, Coupland C, Brindle P. Development and validation of QRISK3 risk prediction algorithms to estimate future risk of cardiovascular disease: prospective cohort study. BMJ 2017; 357: j2099. DOI: https://doi. org/10.1136/bmj.j2099

72. Woodward M, Brindle P, Tunstall-Pedoe H, et al. Adding social deprivation and family history to cardiovascular risk assessment: the assign score from the Scottish Heart Health Extended Cohort (SHHEC). Heart 2007; 93(2): 172-176. DOI: https://doi.org/10.1136/hrt.2006.108167

73. Stevens RJ, Kothari V, Adler Al, et al. The UKPDS risk engine: a model for the risk of coronary heart disease in type II diabetes (UKPDS 56). Clin Sci 2001; 101(6): 671-679. DOI: https://doi.org/10.1042/cs1010671

74. Conroy RM, Pyörälä K, Fitzgerald AP, et al. Estimation of ten-year risk of fatal cardiovascular disease in Europe: the score project. Eur Heart J 2003; 24(11): 987-1003. DOI: https://doi.org/10.1016/S0195-668X(03)00114-3

75. Assmann G, Cullen P, Schulte H. Simple scoring scheme for calculating the risk of acute coronary events based on the 10-year follow-up of the prospective cardiovascular Münster (PROCAM) study. Circulation 2002; 105(3): 310-315. DOI: https://doi.org/10.1161/hc0302.102575

76. D'Agostino RB, Vasan RS, Pencina MJ, et al. General cardiovascular risk profile for use in primary care: the Framingham heart study. Circulation 2008; 117(6): 743-753. DOI: https://doi.org/10.1161/CIRCULATIONAHA.107. 699579

77. Jackson R. Updated New Zealand cardiovascular disease risk-benefit prediction guide. BMJ 2000; 320(7236): 709-710. DOI: https://doi.org/10.1136/bmj.320.7236.709

78. World Health Organization, International Society of Hypertension. WHO/ISH cardiovascular risk prediction charts. 2007; http://www.who.int/cardiovascular_diseases/guidelines/Chart_predictions/en (accessed 22 Sep 2020).

79. Rothwell PM, Giles MF, Flossmann E, et al. A simple score (ABCD) to identify individuals at high early risk of stroke after transient ischaemic attack. Lancet 2005; 366(9479): 29-36. DOI: https://doi.org/10.1016/S0140-6736(05) 66702-5

80. Johnston SC, Rothwell PM, Nguyen-Huynh MN, et al. Validation and refinement of scores to predict very early stroke risk after transient ischaemic attack. Lancet 2007; 369(9558): 283-292. DOI: https://doi.org/10.1016/S01406736(07)60150-0 
81. Merwick A, Albers GW, Amarenco P, et al. Addition of brain and carotid imaging to the $A B C D^{2}$ score to identify patients at early risk of stroke after transient ischaemic attack: a multicentre observational study. Lancet Neurol 2010; 9(11): 1060-1069. DOI: https://doi.org/10.1016/S1474-4422(10)70240-4

82. National Institute for Health and Care Excellence. Stroke and transient ischaemic attack in over 16s: diagnosis and initial management. NG128. 2019; https://www.nice.org.uk/guidance/ng128 (accessed 22 Sep 2020).

83. Johnston SC, Gress DR, Browner WS, et al. Short-term prognosis after emergency department diagnosis of TIA. JAMA 2000; 284(22): 2901-2906. DOI: https://doi.org/10.1001/jama.284.22.2901

84. Gage BF, Waterman AD, Shannon W, et al. Validation of clinical classification schemes for predicting stroke: results from the National Registry of Atrial Fibrillation. JAMA 2001; 285(22): 2864-2870. DOI: https://doi.org/10.1001/ jama.285.22.2864

85. Lip GYH, Nieuwlaat R, Pisters R, et al. Refining clinical risk stratification for predicting stroke and thromboembolism in atrial fibrillation using a novel risk factor-based approach: the Euro Heart Survey on Atrial Fibrillation. Chest 2010; 137(2): 263-272. DOI: https://doi.org/10.1378/chest.09-1584

86. Pisters R, Lane DA, Nieuwlaat R, et al. A novel user-friendly score (HAS-BLED) to assess 1-year risk of major bleeding in patients with atrial fibrillation: the Euro Heart Survey. Chest 2010; 138(5): 1093-1100. DOI: https://doi. org/10.1378/chest.10-0134

87. Wells PS, Hirsh J, Anderson DR, et al. A simple clinical model for the diagnosis of deep-vein thrombosis combined with impedance plethysmography: potential for an improvement in the diagnostic process. J Intern Med 1998; 243(1): 15-23. DOI: https://doi.org/10.1046/j.1365-2796.1998.00249.x

88. Wells PS, Anderson DR, Rodger M, et al. Derivation of a simple clinical model to categorize patients probability of pulmonary embolism: increasing the models utility with the SimpliRED D-dimer. Thromb Haemost 2000; 83(3): 416-420.

89. Le Gal G, Righini M, Roy P-M, et al. Prediction of pulmonary embolism in the emergency department: the revised Geneva score. Ann Intern Med 2006; 144(3): 165-171. DOI: https://doi.org/10.7326/0003-4819-144-3-20060207000004

90. Wicki J, Perneger TV, Junod AF, et al. Assessing clinical probability of pulmonary embolism in the emergency ward a simple score. Arch Intern Med 2001; 161(1): 92-97. DOI: https://doi.org/10.1001/archinte.161.1.92

91. Aujesky D, Obrosky DS, Stone RA, et al. Derivation and validation of a prognostic model for pulmonary embolism. Am J Respir Crit Care Med 2005; 172(8): 1041-1046. DOI: https://doi.org/10.1164/rccm.200506-8620C

92. Jiménez D, Aujesky D, Moores L, et al. Simplification of the pulmonary embolism severity index for prognostication in patients with acute symptomatic pulmonary embolism. Arch Intern Med 2010; 170(15): 1383-1389. DOI: https:// doi.org/10.1001/archinternmed.2010.199 